\title{
THE OUTSOURCING URBAN MOBILITY IN INDUSTRY 4.0 AND THE CHALLENGES FACED BY THE CATEGORY OF WORKERS IN SEARCH OF RIGHTS AND OCCUPATIONAL SAFETY
}

\author{
Fabio Junio Rodrigues da Silva ${ }^{1}$, Adriano Silvestre Fernandes ${ }^{2}$, Carlos Eduardo de Carvalho \\ Costa $^{3}$, Ilidiane Correia de Oliveira ${ }^{4}$, Robson Edgard Faria ${ }^{5}$ and David Barbosa de Alencar ${ }^{6}$
}

\author{
1, 2, 3, 4, 5 Blauro Cardoso de Mattos Higher Education Institute - FASERRA. Manaus - Amazonas, Brazil. \\ ${ }^{6}$ Galileo Institute of Technology and Education of the Amazon - ITEGAM. Manaus - Amazonas, Brazil.
}

Email: f.fabiojunio28@gmail.com, silvestrekalu@gmail.com, ecarloscarvalho39@gmail.com, lidia_oliveira21@hotmail.com, robsonedfaria@yahoo.com.br, david002870@hotmail.com

Received: May 11 $11^{\text {th }}, 2020$

Accepted: Jun 05 ${ }^{\text {th }}, 2020$

Published: June $30^{\text {th }}, 2020$

Copyright (C2016 by authors and Galileo Institute of Technology and Education of the Amazon (ITEGAM).

This work is licensed under the Creative Commons Attribution International License (CC BY 4.0).

https://creativecommons.org/licen ses/by/4.0/

\section{Opea Actes:}

\begin{abstract}
This article has as its central scope to capture the challenges faced by service providers for delivery applications and urban mobility on demand such as Uber, 99POP, iFood, Rappi, among others, a profession that has emerged with innovations in technology and Industry 4.0, which with the Brazilian economic crisis, a mass of workers changed their careers out of necessity and faced new challenges, with a category that is not recognized by law, there are flaws in terms of job security, and the study will also analyze the main diseases and injuries acquired while working. In addition to highlighting other risks faced by this new category of workers, such as urban violence in large cities. For this, a descriptive research was carried out with qualitative and quantitative analysis of data using books, articles, dissertations, newspapers and magazines to support the analysis of the content extracted from the interviews that took place from January/2020 to March/2020, where it was possible to know and describe the routine, the difficulties, as well as the activities that directly affect the health and safety of this service provider's work.
\end{abstract}

Keywords: Safety, Uber, Apps.

\section{INTRODUCTION}

Recalling a past not far from where you had to call for taxi radio company to request a rush to place " $\mathrm{x}$ " at a variable rate according to the distance, and the customer had no idea how that race would cost at the beginning of it. And thinking about the times when small entrepreneurs, mainly in the food industry, they would have to hire their employees correctly through CLT (Consolidation of Labor Laws) and had obligations to that worker, ensuring the quality of services, employee safety and still bear the operating costs of that activity.

It is impossible not to notice how the current times have changed so much with the "Uberization" of work, according to the lawyer, Specialist in Individual and Collective Labor Law Tatiana Moreira Rossini, where the demands have become more frantic and the labor ties for these on-demand services have become just service delivery partnerships, where companies have the sole obligation to pay for the service provided. On-demand applications, arose from the idea of connecting idle workers to customers who needed specific services in a certain area, thus the great technology startups were born that manage the infrastructure of the most known applications in the world, such as Uber, 99POP, Cabify, InDrive [1]. In fact, it became much easier for customers to request an Uber, or any other urban mobility application on demand, to go from location "A" to "B" with flat rates, practical when requesting the service through an app (in seconds, or order your favorite snack from the comfort of your home through an iFood, Rappi, Uber Eats and have your food for a relatively low price and still have an estimated delivery time for that favorite dish. With the use of these apps from big famous startups that we know, it originated in a new working reality, where these startups have large digital platforms bringing together customers and service providers that use their labor to make a profit and deliver a demand, and the user is a mere user of the service and attributing qualification grades for the service provided. Through these simple examples we can see how we are evolving our services: greater 
comfort, practicality, quality and speed, but looking through another spectrum, how does that worker live? Does he have an adequate quality of life with the service he performs? Does he have his labor rights guaranteed by law? What about your safety at work? Do companies that need your services have adequate work safety planning that can reduce risks for this worker?

The reality is that at this point raised by this article, very little have evolved, after all, is only providing service, and this developer is in an occupational dilemma where there are no laws, specific standards that compare in relation to labor laws, health and safety standards, until then they only have the right to Social Security, which through decree, classified them as individual microentrepreneurs (MEI).

\section{DEVELOPMENT}

It is undeniable the fact that the current technologies, advances in research and development, IoT, Industry 4.0 itself aim to facilitate work processes, efficiency and greater management control and increased productivity in all areas of a company. Speaking of applications on demand, we can analyze that startups facilitated connectivity between consumer vs. services, and in this middle there is the worker, a figure active in this process as the executor of the cheap labor offered by startups.

It can be easily noticed that it is not just a digital transformation, automation processes, but also a transformation of people, organizational methods and Work Safety is linked to this indispensable factor in labor relations, the Human Being, on how to adapt the work so that that work activity does not affect physical, cognitive and organizational health in a given daily life.

Through various literature, Industry 4.0 has the purpose of conducting research and innovating methods that can boost the effectiveness of procedures in a substantially high way, in such a way that it can help companies in their various sectors of activity, integrating them for a greater control, through automated information systems in processes ranging from manufacturing, logistics services and urban mobility, causing the complexities of these processes to be drastically reduced, reducing their costs but not their quality [2].

In the history of mankind we have important points to note in order to determine the transformation in industrial processes. The first industrial revolutions established the implantation of machines, electricity and technological information, automating repetitive processes aimed at the productivity and physical health of employees. Nowadays, with the spread of IoTs and services in manufacturing, the $4^{\text {th }}$ Industrial Revolution begins.

This concept of Industry 4.0 emerged in Germany in 2011, as a means to create a new concept of that country's national economic policy based on high-tech strategies and solutions, incorporating digitization and Artificial Intelligence (AI) into industrial activity, which culminated in the concept that we know as Industry 4.0, in reference to a 4th Revolution in the world industry, characterized by integrating control information, and several interconnected processes in the network and the fusion of these means for our reality [3].

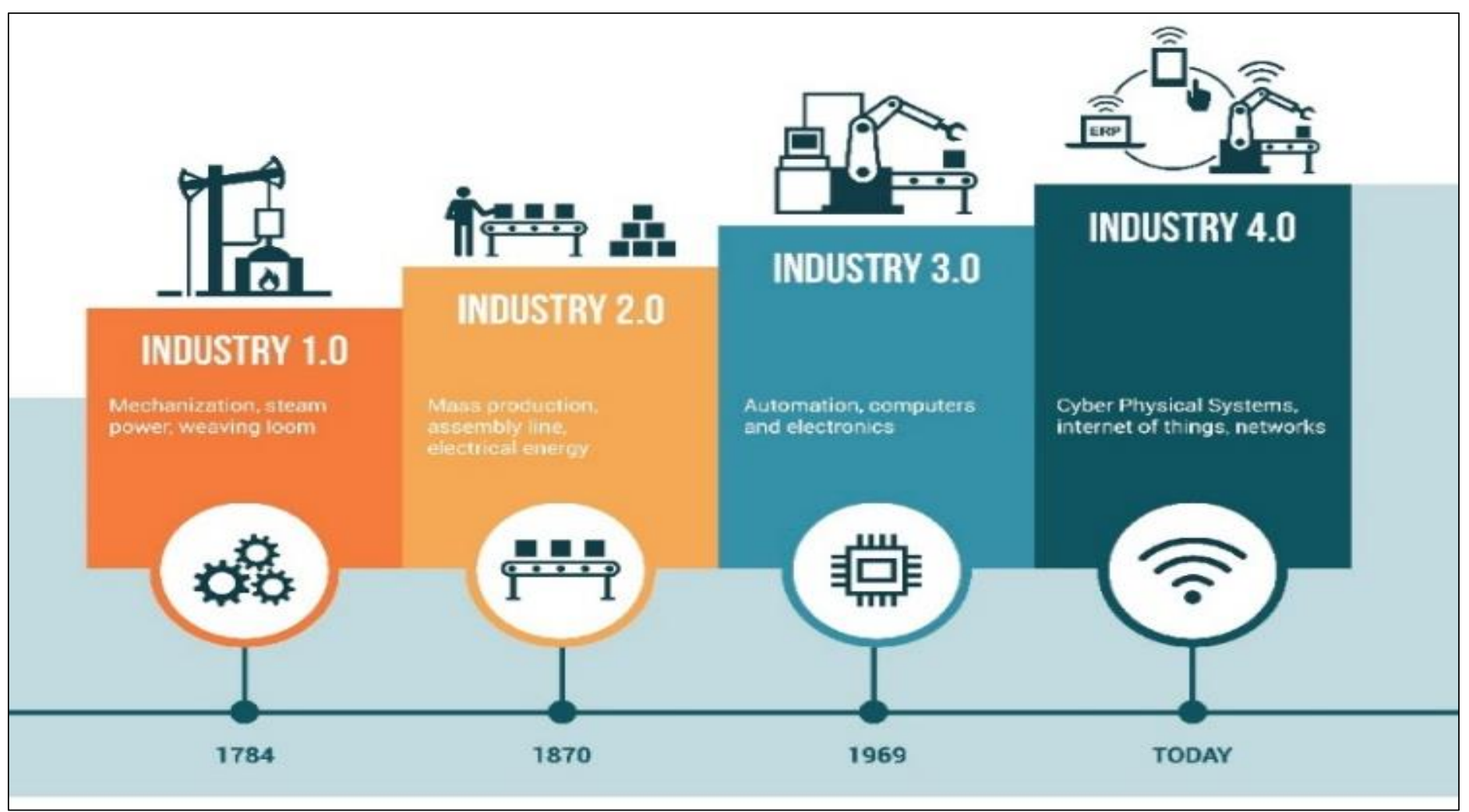

Figure 1: Timeline of Industrial Revolutions.

Source: [2].

The transformation in working methods over the years, as shown in Figure 1, became clear to our eyes, we see the replacement of human labor, by the automation of processes, the replacement of some decision making by AI, some common professions being totally shaken by the different ways of working. One of these markets are urban mobility and on-demand services.
Taxi drivers and Delivery couriers, as well as the craftsmen of the first industrial revolution, were very knowledgeable about their profession and felt great impacts due to the changes that occurred. The knowledge of paths and paths in large Brazilian cities consolidated the career of many workers who made it their livelihood for their family, and in the current times 
they have come to face a tough competition from drivers and deliverers of digital platforms, and such knowledge digital has given them the facility to travel in lesser-known roads in cities by GPS, and also by the easy access of their consumers through smartphone applications, enabled this new market of mobility and service on demand bringing a higher cost benefit and quality to the sector [4].

Looking at this scenario with all these facts exposed, we can see how efficient and productive the transformations coming from Industry 4.0 are, with their flexibility, speed and ease of handling for their consumers. We cannot forget the environment in which the worker faces in his day-to-day working via apps.

The innovation that these companies brought in this new model of work is related to an amplification of freedom, where people offer their services and do it without bureaucracy and without bosses while people wish to enjoy these services for a certain period of time and paying only for the fraction that are going to use. Other determining factors explain the success of this model, in addition to unemployment, the promise of quick and easy gains, and autonomy in conducting one's own work.

What happens is that the freedom offered in this modality of work encounters a limitation of encountering practical life, where the worker needs an initial income to pay for the maintenance of basic survival needs, therefore, they are subjected to exorbitant working conditions. It is noted that such practices are shown as a new model for the appropriation of profits for large investors, leaving the workers only to contribute with their wealth and workforce, totally different from the fallacious idea of selfemployed [5].

In the last decade, we lived in Brazil an economic crisis unprecedented in the history of the country, sweeping jobs from different sectors, and it was a natural way for professionals to have a means of support and adhere to applications. Of all the workers in this sector, $12 \%$ are attending or have not completed higher education and $5 \%$ have completed their degree, as cited by IBGE (Brazilian Institute of Geography and Statistics). The study does not mention whether there was an increase in this percentage [6].

When examining some studies, they can reveal the precarious aspects of this work, via applications, which mention long working hours, low remuneration, lack of labor rights, however the lack of job security is a little discussed and more harmful, both to the physical, cognitive and financial health of this worker, where he must still bear the operational costs of this work, having to make long hours to cover achieving a good monthly income [1].

All the technology apparatus of the big startups in the specific sector of work mediated by applications is the reason that companies hide their true activity. They register with regulatory agencies as "technology companies" and call themselves as a simple platform administrator and that their role is only to mediate the meeting of service providers and consumers, earning a percentage fee for each service performed by this meeting. In this way, they understand that their only obligation is to provide and maintain the adequate infrastructure for these employees to do their services and find hundreds of customers per day. And not taking responsibility for what happens before, during and after providing the service, leading drivers and delivery people to various problems and losses [6].

When workers are submitted to such working conditions, they are prone to countless occupational diseases such as stress, headaches, anxiety to meet daily goals to meet operating costs and still obtain personal profits, depression, etc. [7].

Due to the frantic routine in search of customers and races to the applications can cause Cardiovascular Diseases, due to the busy routines in the traffic, long distances, long working hours. As a result, these workers assume the risk of causing heart disease. Diabetes, due to poor diet, of course, there are cases that the genetic predisposition favors a lot, and its symptoms are mild, such as blurred vision, excessive thirst, etc.

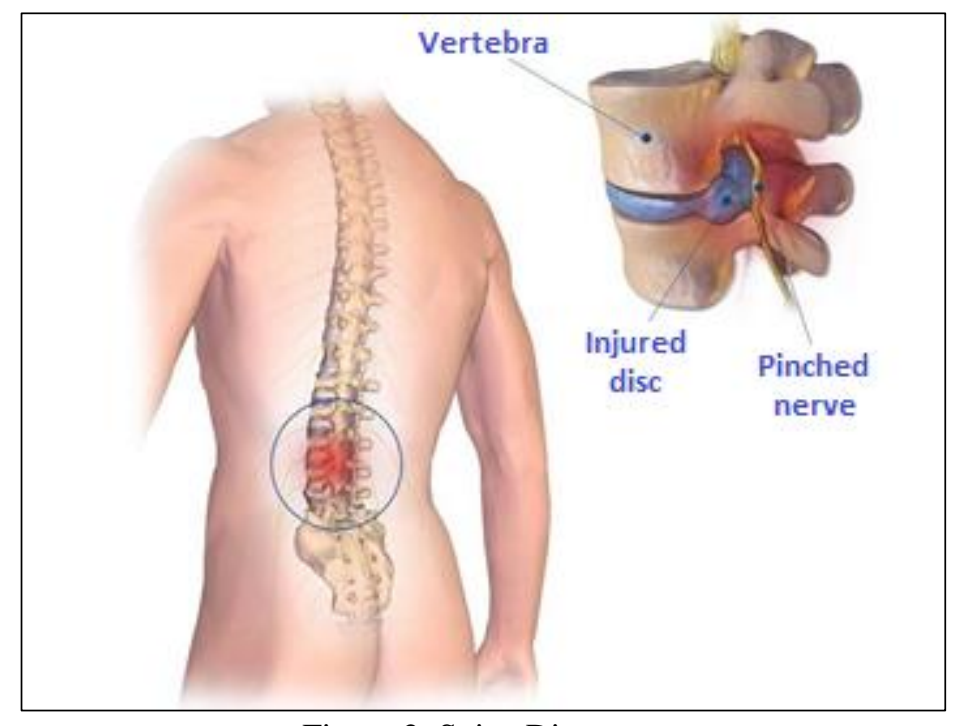

Figure 2: Spine Diseases.

Source: [8].

Spine diseases, for spending hours sitting, using repetitive movements to drive the vehicle or motorcycle, too often with the seat unregulated, which greatly favors the appearance of occupational diseases that affect the spine [9].

Experts indicate that long working hours in traffic can cause discomfort in the legs, in the quadriceps (anterior thigh muscle), in the knee cap and even in the cervical spine, whose force on the discs is stronger when the person is sitting [10].

Professional drivers are more likely to develop herniated discs. This is because, spending many hours sitting, the tendency of drivers is to relax the trunk, placing all their weight on the bones of the lumbar spine and pelvis. The discs are like 'shock absorbers' that exist between the vertebrae. They are composed of an outer ring, which covers the soft center (core), almost all composed of water. Disc injuries can result from a rupture of the disc. This causes the soft center to be forced outward or to break, sometimes even pressing on the nerves of the spinal channels. This is called a herniated disc [11].

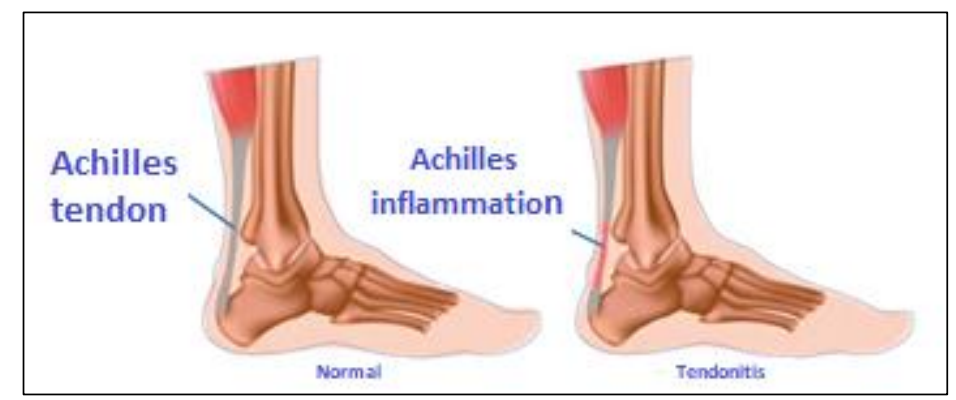

Figure 3: Achilles tendonitis.

Source: [12].

In these cases, it is common for a person to have tendonitis in the achilles tendon and pain in the calf, as shown in Figure 3. Achilles tendinitis (also called Achilles tendinopathy or calcaneus tendinitis) is an inflammatory condition that affects the Achilles tendon. The Achilles tendon is a large tendon that connects the calf muscle (calf) to the heel bone. Achilles tendonitis can be diagnosed 
based on symptoms and physical examination of the ankle and tendon. It particularly affects drivers, who are workers who use repetitive effort in the area of the feet and legs to execute commands to accelerate, clutch and brake the car [13].

Motorcyclists are also not free from occupational injuries that likewise happen due to repetitive effort due to long working hours, braking, changing gears, acceleration, movements to turn the handlebars, muscular force applied to these movements and incorrect posture (postural vices). Carpal tunnel syndrome in the wrists or other parts of the body such as elbow tenosynovitis and supraspinatus tendonitis (shoulder) are the most common for motorcyclist workers. It is necessary to remember that there is a risk factor that accelerates these degenerative processes which is the segmental vibration (arms) and the whole body. The vehicle vibrates due to its softness and on uneven floors [14].

As in any other profession, stress is strictly linked to the activity of drivers and app deliverers. A 2011 survey by Detran/RS (Traffic Department of Rio Grande do Sul) reported that professional drivers diagnosed with stress and involved in accidents are due to lack of attention and sleep, it is noted that there is a strict connection with the long working hours. The interaction between the worker and the chaotic environment in which he remains during his work routine is the determining factor for the development of stress, and the negative effects of stress only tend to worsen when there are no resources to adapt the routine, or to solve personal problems. reflected in all areas of the individual's life.

The stress generated by stress causes discomfort, tiredness, insomnia, decreased pace of life and the ability to maintain physical and mental balance in daily activities, generating catastrophic health effects and personal and family relationships [15].

It is undeniable that the routine of these workers has a high propensity to acquire stress, especially because they have to bear all the operational costs and still take risks with traffic and urban violence, it raises a high propensity to suffer from a high burden. mental, high cognitive and psychic burdens arising from personal concerns, pressure to hit daily goals for their livelihood, as well as getting rid of assaults in large cities [16].

In addition to occupational diseases that these employees are predisposed to suffer, they are at serious risk with the violence of the streets of the great cities of Brazil, where they can be assaulted, assaulted, stolen their profits obtained from their work, but also have their vehicle (car/motorcycle) stolen by bandits, this situation is even more alarming when there are cases of collaborators, women are at risk, and may be harassed, raped, stolen or any other type of violence.

Brazil still suffers from a deficiency in social protection of application regulation, and employees also lack security, be it labor, occupational or legal, generating dependency. And there is also a lack of public policies that regulate such deficiencies, it is noted that for the leaders of these large startups, the growth of this type of work precarious in rights and duties does not lose strength and there is no prospect that this will change if there is no action regulatory powers. Promoting forms of work that are not precarious and harmful to workers is fundamental in our society today.

It can be noted that for the time being the state strives to adapt itself to the contemporary and national economy, without worrying about the fundamental rights of workers (providing a kind of insurance for drivers, limitation of hours worked, establishment of a minimum salary ceiling for employees, medical assistance and training in routine job security, etc.) by these companies to their socalled "partners", and corporate thinking is only about capital accumulation. Abandoning their collaborators under the law, where they should be at the same level [17].

\section{MATERIALS AND METHODS}

The instruments used for data collection were the individualized interview with workers combined with on-site observation of the routine, data collection tools and search filters such as Google Forms, and messaging platforms such as Skype and WhatsApp for communicating with drivers and application deliverers.

In the stage of preparing and applying the interview with these workers, the typology of deductive research was used, so that it was not invasive and did not reach the privacy and individuality of each group, but that it obtained results and concise answers to what the research requires. It is noteworthy that informal questions were asked where drivers and couriers could be comfortable with the questions and answers were spontaneous and realistic.

The interviews took place from January/2020 to $\mathrm{March} / 2020$. These workers are from several cities in the country, such as: Manaus/AM, Iranduba/AM, São Paulo/SP, Diadema/SP, Itapevi/SP, Cubatão/SP, Santos/SP, São Bernardo do Campo/SP, São Vicente/SP, Rio de Janeiro/ RJ, São João de Meriti/RJ, Campos dos Goytacazes/RJ, Teresópolis/RJ, Belo Horizonte/MG, Juiz de Fora/MG, Divinópolis/MG, Curitiba/PR, Maringá/PR, Cuiabá/MT, Teresina/PI and Brasília/DF.

Table 1: Number of respondents by Brazilian state.

\begin{tabular}{|c|c|}
\hline State & Number of respondents \\
\hline Amazonas & 5 people \\
\hline Distrito Federal & 4 people \\
\hline Mato Grosso & 1 person \\
\hline Minas Gerais & 4 people \\
\hline Paraná & 5 people \\
\hline Piauí & 1 person \\
\hline Rio de Janeiro & 8 people \\
\hline São Paulo & 14 people \\
\hline TOTAL & $\mathbf{4 2}$ people \\
\hline
\end{tabular}

Source: Authors, (2020).

The only criterion used to choose the interviewees was the experience and daily performance as a service provider partner (Drivers and Deliverers) of on-demand service applications.

The following questions were asked of workers:

- Name and Age?

- Genre?

- Education level?

- Which applications does the worker provide services for?

- Total or partial financial dependence on work for applications?

- How many hours do you work a day?

- How much do you need to earn per day to have a minimum income to cover operating costs of work and basic needs of the home?

- Have you been in pain in any part of your body since you started working for apps?

- Do you agree with job safety training for apps drivers and delivery couriers? 
- Would you like the profession to be regulated and have more labor rights?

- Have you suffered any kind of urban violence? Describe it.

The questionnaire method is the most used among the methodologies of collecting data. Today, people are more familiar with approaching interviewers at any time of the day. It is a versatile tool, almost all research problems can be addressed through a questionnaire. It is usually faster and more practical than observation [18].

The author values ethics as a differential factor in the performance of the research, the questions had a neutral character, as a way of not influencing the answers.

\section{RESULTS AND DISCUSSION}

This is a descriptive, cross-sectional research with quantitative and qualitative data analysis. The present study has a descriptive character, as it aims to know the worker's routine, the difficulties that he faces every day, as well as the activities performed that directly affect the health and safety of work in this category.

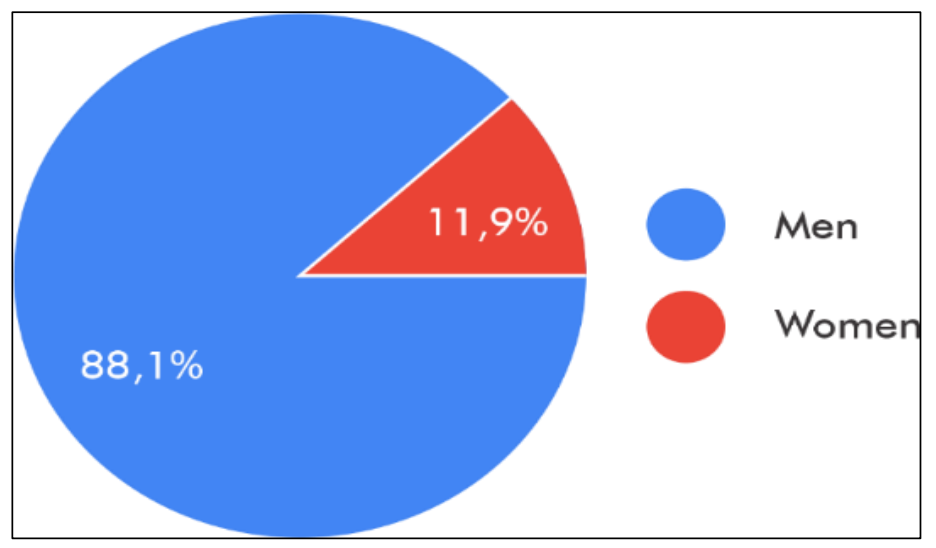

Figure 4: Population Gender.

Source: Authors, (2020).

According to this study, the sample of verified population that works via on-demand applications is mostly men than women, in the scenario of this article Figure 4 shows that $88.1 \%$ of the interviewees claim to be men, and $11.9 \%$ are women.

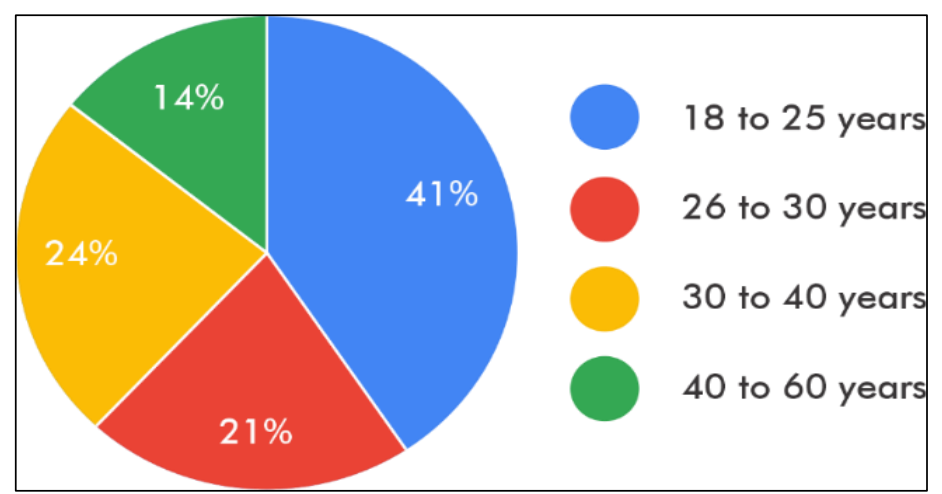

Figure 5: Population Age. Source: Authors, (2020).

This present study mentions that in the last decade Brazil has suffered an unprecedented economic crisis, sweeping jobs, which is why it has opened new markets, such as on-demand application startups, which has led a mass of workers to look for a new type of family income for their livelihood.

The Figure 5 shows that $41 \%$ of the population verified in this study is between 18 and 25 years old, this can be translated with the loss of jobs of people, unemployed individuals, or who are starting their professional career and have not yet had a job. job opportunities, which can be equivalent to the first job, those support positions such as: production assistants, machine operators, call center attendant, receptionist, etc., and these people saw in this application service market on demand a means to stay financially and enter the market without so much bureaucracy to start.

The other ages shown have a certain balance as some have higher education and managed to remain in their positions, and those who did not keep on working for applications on demand, as they face difficulties for professional replacement in their area of origin, either due to lack vacancies, lack of professional qualification or old age.

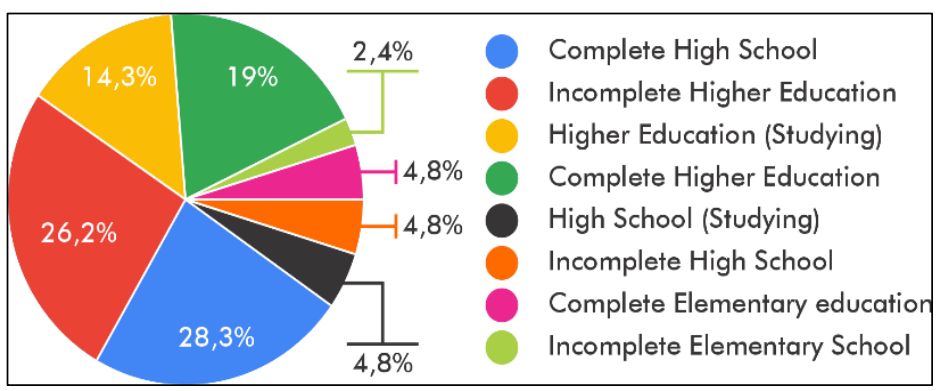

Figure 6: Education level.

Source: Authors, (2020).

The Figure 6 shows that the majority of drivers and delivery couriers of on-demand apps have Incomplete Higher Education, $26.2 \%$, due to the remuneration from the activity having to be shared with the operational costs all in charge of the worker, they reported that they had to lock up their Higher Education courses so that they could reallocate their financial resources to the areas of basic needs of their families. The Figure 6 also shows that all classes, regardless of education, were affected and depend on this activity.

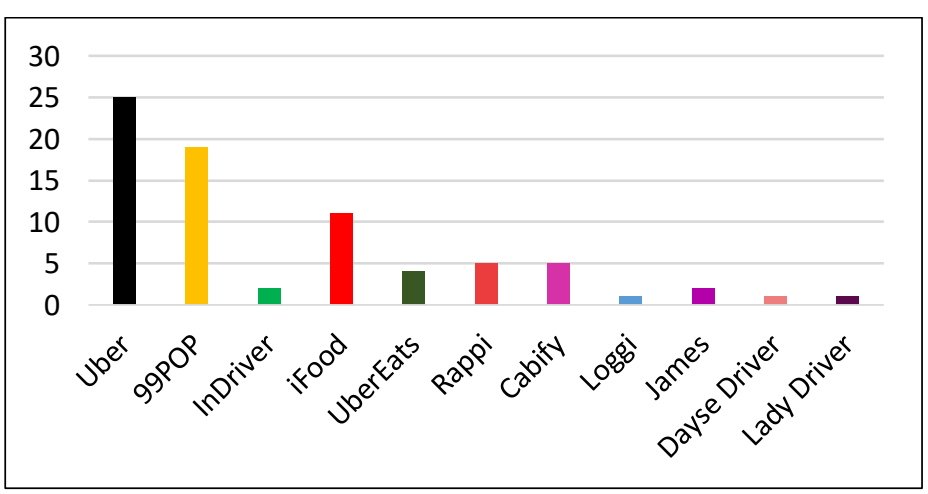

Figure 7: Applications used by the interviewees as a means of work.

Source: Authors, (2020).

From the universe of on-demand service applications, respondents mentioned that they work for Uber, for being a pioneer in the country in this modality and for offering a greater number of customers per hour. For on-demand delivery applications we have iFood as a reference, using the same argument as Uber, offering a greater number of restaurants registered on the platform, in other 
words, giving fluidity to a greater number of customers per hour, as exposed by the frequency of use of applications in Figure 7.

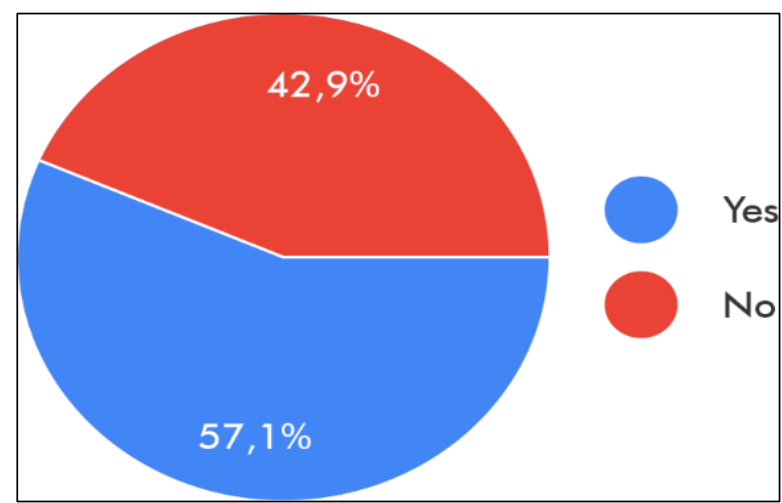

Figure 8: Financial dependence on income from applications. Source: Authors, (2020).

Respondents were asked whether the income collected from driving and delivering work for on-demand applications was unique and necessary, or just a financial supplement for the family, $57.1 \%$ reported that it depends only on this income, being this only source of financial resources for your basic monthly needs. The other party reported that the work reported that the provision of services for applications was only to increase the family's monthly income, complementing the other type of work that the person does, according to what is shown in Figure 8.

Respondents were encouraged to describe their work routines, so most described that they usually work every day, from Monday to Sunday to obtain an adequate monthly income at the end of the month, some stated that they work 12 to 15 hours a day to collect between $\mathrm{R} \$ 200.00$ to $\mathrm{R} \$ 300.00$ per day to meet operating costs, such as maintenance, fuel, and to meet the needs of their homes.

Most of them said they get up early and sleep an average of 6 hours a day, leaving early and returning home late, they described the routine as being tiring and stressful, due to the constant and busy traffic in their cities. A large part of the interviewees reported being harassed by customers, being accused of stealing from their customers, either due to the high rate indicated in the application, or the food arriving cold, due to the difficulty of access to the delivery place, which greatly increases the degree of stress on workers who depend on this service to survive, customers assign grades to the service, if low grades occur the worker can be blocked from the application, thus preventing him from working normally.

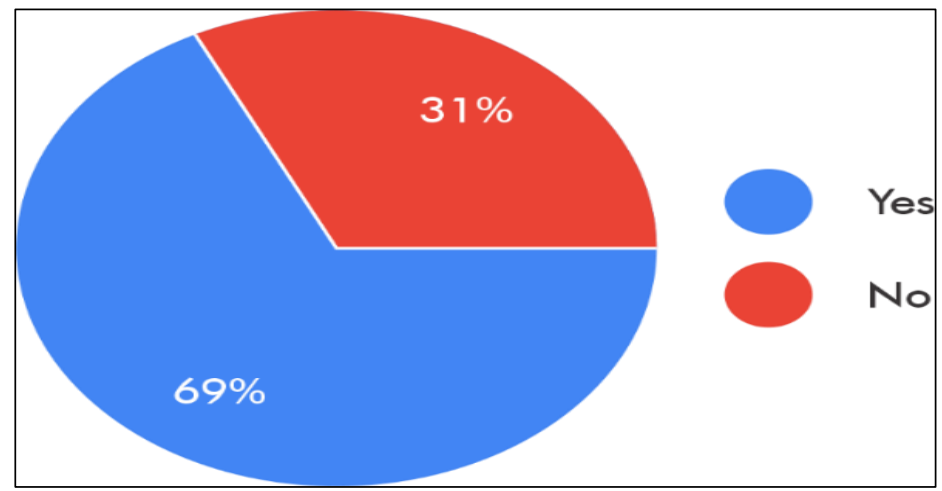

Figure 9: Traumas and injuries.

Source: Authors, (2020).

The workers were asked if they feel pain in the body due to working for on-demand applications, $69 \%$ of them stated that
Yes, according to Figure 9. Then they were asked what types of pain they feel, which describe where and how the pain is and how long have they been experiencing these symptoms. They said they felt pain in the feet, legs, calf, hands, back pain, low back pain, pain in the arms, pain in the neck, headache. We can see that these are the regions where the greatest repetitive efforts occur due to labor activity. One person claimed to have developed depression due to work stress and financial concerns.

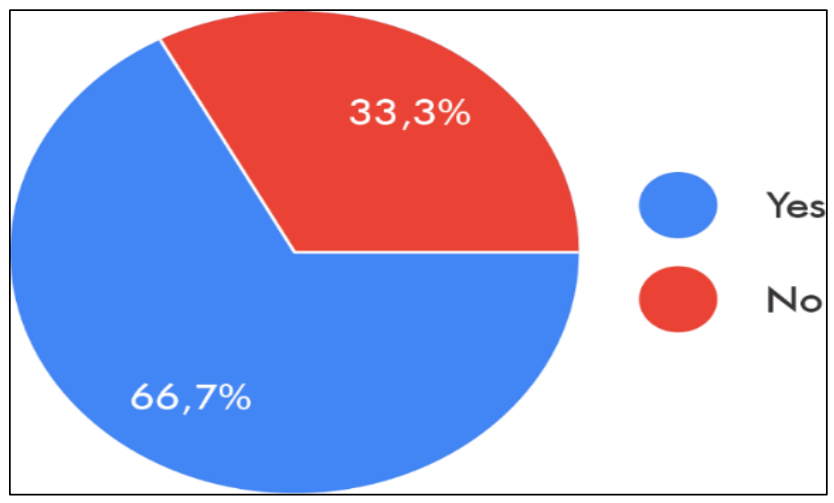

Figure 10: Work Safety and Labor Rights.

Source: Authors, (2020).

Respondents were asked what they thought about having work safety rights and training when exercising the activity and their guaranteed labor rights. The majority of $66.7 \%$ stated that they wished to have access to worker safety training on the part of application companies, so they would avoid the profession's risks when performing the activity, regarding labor rights, in addition to the majority agreeing that they should have labor rights guaranteed by law, as shown in Figure 10.

Workers informed that they should be better recognized by labor laws, have health insurance coverage, fixed working hours, limited daily workload, operating allowance or fuel vouchers, annual profit sharing, some type of health insurance for exposure to urban violence, guarantee fund and unemployment insurance. They reported that just being MEI does not guarantee much quality of life, as it only contributes a percentage of their Social Security to the INSS (National Institute of Social Security), but they live and work as if they were informal workers.

Drivers and delivery couriers were asked about urban violence, they reported having been robbed, having their goods taken away, such as a work vehicle and smartphone. Only 5\% of the interviewees reported having suffered physical aggression, which increased the pathology of injuries acquired at work.

\section{CONCLUSIONS}

This article concludes that special attention is needed for this new work niche that has emerged with advances in industry and new technologies through on-demand service applications. When analyzing the facts exposed in this study, it can be noted that there is still a lack of improvement in regulations and health and safety at work for the category of apps drivers and deliverers, they live in a scenario of false protection of the law through the MEI (Individual Microentrepreneur), but with working conditions as if they were informal workers. And so they develop injuries, traumas, and stress itself, which is the general factor of all the difficulties together in the profession.

It is possible to affirm that there is a precarious scenario in this category of workers and there is much to be done, recent legal decisions still rule out the possibility of regulation of the profession and improvements being made. Workers and society 
need to claim their rights and make them recognize that this modality is essential nowadays, we have gone through a pandemic period of SARS-CoV-2, named by WHO (World Health Organization) as COVID-19 (Corona Virus Desease - 2019), and these workers were still one of the few who were in full activity making the country's economy work and many businesses, mainly restaurants and stores were not totally paralyzed, and other sectors benefited from the activity of these workers, with transportation and delivery of goods, enabling all sectors to reinvent themselves, with the fundamental participation of this sector studied in this article.

There is a lot that needs to be done to ensure that work health and safety is effectively guaranteed for this category, but at least we can highlight some initiatives by the big startups that are already starting to change this situation, where Uber limits the maximum workload to 12 hours. performance in the application [19], or iFood that announced that it will have insurance, courses and health insurance discounts for its partners [20].

\section{REFERENCES}

[1] Moraes, R. B. S.; Oliveira, M. A. G.; Accorsi, A. Uberização do trabalho: a percepção dos motoristas de transporte particular por aplicativo. Revista Brasileira de Estudos Organizacionais - v. 6, n. 3, p. 647-681, dez/2019.

[2] Industry 4.0 and Industrial IoT in Manufacturing: A Sneak Peek. Available in: <https://www.aberdeen.com/opsproessentials/industry-4-0-industrial-iot-manufacturing-sneakpeek/>. Accessed on 06/03/2020.

[3] Becker, A. Schneider, A. Ercico, J. Werlang, R. Os Conceitos da Indústria 4.0 Associados a Abordagem da Capacidade Dinâmica. ANAIS - Engenharia de Produção. UCEFF. 2018.

[4] Souza. M. A indústria 4.0 e os artesãos da era digital. Available in: <https://www.industria40.ind.br/artigo/19652-a-industria-40-eos-artesaos-da-era-digital>. Accessed on 29/03/2020.

[5] Rubenich, R. S. A Possibilidade de Configuração da Relação de Emprego Entre a Uber e os Seus Motoristas. Âmbito Jurídico. 2020. Available in: <https://ambitojuridico.com.br/cadernos/direito-do-trabalho/apossibilidade-de-configuracao-da-relacao-de-emprego-entre-auber-e-os-seus-motoristas/>. Accessed on 06/03/2020.

[6] Uber com diploma. Available in: $<$ https://economia.uol.com.br/reportagens-especiais/profissionaiscom-faculdade-viram-uber/\#uber-com-diploma>. Accessed on 06/03/2020.

[7] Pina, J. A. Intensificação do trabalho e saúde dos trabalhadores na indústria automobilística: estudo de caso na Mercedes Benz do Brasil, São Bernardo do Campo. Tese apresentada para obtenção do título de Doutor em Ciências na área de Saúde Pública. Escola Nacional de Saúde Pública Sérgio Arouca - ENSP. FIOCRUZ. 2012.

[8] Hérnia de Disco. Available in: $<$ https://www.bauerfeind.com.br/blogs/news/hernia-de-disco>. Accessed on 05/05/2020.

[9] Almeida, L. M. Ideias de Negócio - Transporte por aplicativo. Empreendedorismo. SEBRAE. 2019.
[10] Rodrigues. E. O peso da embreagem: Para e arranca no trânsito pode virar doença crônica. 2014. Available in: $<$ http://www.diariogaucho.clicrbs.com.br/rs/dia-a-

dia/noticia/2014/06/para-e-arranca-no-transito-pode-virar-doencacronica-4519338.html>. Accessed on 01/05/2020.

[11] Motoristas têm mais chances de desenvolver Hérnia de Disco. Available in $<$ https://www.transaltransportes.com.br/dicas/motoristas-temmais-chances-de-desenvolver-hernia-de-disco>. Accessed on 01/05/2020.

[12] O que é tendinite de Aquiles? Available in: $<$ https://www.saudebemestar.pt/pt/clinica/ortopedia/tendinitetendao-aquiles/>. Accessed on 01/05/2020.

[13] Tendinite de Aquiles. Available in: $<$ https://ada.com/pt/conditions/achilles-tendonitis/>. Accessed on 01/05/2020.

[14] Brito, P. Movimentos repetitivos no trânsito causam doenças em motociclistas. Available in: < http://www.perkons.com.br/pt/noticia/1301/movimentosrepetitivos-no-transito-causam-doencas-em-motociclistas $>$. Accessed on 01/05/2020.

[15] Martins, F. F.; Lopes, R. M. F.; Farina, M. Nível de estresse e principais estressores do motorista de transporte coletivo. Bol. Acad. Paulista de Psicologia, São Paulo, Brasil - V. 34, no 87, p. 523-536.

[16] Costa, E. A. V. G. Estudo dos Constrangimentos Físicos e Mentais Sofridos pelos Motoristas de Ônibus Urbano da Cidade do Rio de Janeiro. Dissertação de Mestrado apresentada ao Programa de Pós-Graduação em Design da PUC-Rio. 2006.

[17] Firmino. V. H. Como a Uber contribui para a precarização do trabalho na modernidade. Available in: $<$ https://vitorfirmino.jusbrasil.com.br/artigos/534725925/como-auber-contribui-para-a-precarizacao-do-trabalho-na-modernidade>. Accessed on 06/03/2020.

[18] Guimarães, P. R. B. Estatística e pesquisa de opinião. Departamento de Estatística - Universidade Federal do Paraná, UFPR, 2020. Available in: <https://docs.ufpr.br/ prbg/public_html/ce020/estatística\%20E\% 20pesquisa\%20de\%20opinião\%201a\%20parte.pdf >. Accessed on 08/05/2020.

[19] Uber lança ferramenta que limita o tempo online do motorista dirigindo usando o aplicativo para promover segurança viária. Available in: <https://www.uber.com/pt-BR/newsroom/uberlanca-ferramenta-que-limita-o-tempo-online-do-motoristadirigindo-usando-o-aplicativo-para-promover-seguranca-viaria/>. Accessed on 02/05/2020.

[20] iFood Delivery de Vantagens. Available in: $<$ https://entregador.ifood.com.br/regulamento-ifood-delivery-devantagens/>. Accessed on 02/05/2020. 